\title{
Implementasi gaya komunikasi asertif orang tua - anak selama masa pandemi covid 19
}

\author{
Suciati Yahono*, Ade Putranto \\ Program Studi Ilmu Komunikasi Fakultas Ilmu Sosial dan Ilmu Politik \\ Universitas Muhammadiyah Yogyakarta \\ Email Korespondensi: *suciatiyahono@gmail.com
}

Received August 28, 2021; Revised October 7, 2021; Accepted October 26, 2021

\begin{abstract}
Abstrak
Melihat kondisi pandemi yang tidak pernah bisa diprediksi kapan berakhirnya, orang tua harus memiliki strategi terhadap anak-anak yang terkungkung di rumahnya sendiri sambil mendengarkan pemberitaan yang memprihatinkan. Orang tua memiliki banyak tugas tambahan selama SFH, antara lain: memperhatikan tandatanda penyakit pada anak jika sesuai dengan gejala Covid-19, tanda-tanda stres pada anak yang berimbas pada kebiasaan makan atau tidur yang tidak sehat, dan kesulitan dengan konsentrasi, mengajarkan dan membiasakan tindakan patuh pada protokol kesehatan. Hal ini bisa mengakibatkan terjadinya konflik antara orangtua dan anak, sebagaimana yang terjadi pada keluarga ibu-ibu PKK di kecamatan Juwiring, Klaten. Berdasarkan hasil observasi yang dilakukan oleh Tim abdimas ternyata ada lima pasang orangtua anak yang terlibat konflik akibat stress selama masa SFH, oleh karena itu tim menawarkan solusi untuk mengatasi permasalahan tersebut. Adapun solusi tersebut adalah dengan mengadakan wawancara \& focus group discussion (FGD) dan penyuluhan "gaya asertif orang tua-anak dalam mewujudkan harmonisasi keluarga". FGD disini bertujuan untuk mengidentifikasi lebih mendetail terkait konflik orang tua anak. Penyuluhan dilakukan untuk meningkatkan pengetahuan dalam menjalani kehidupan rumah tangga pada pasangan orang tua-anak. Berdasarkan hasil pengabdian dapat disimpulkan bahwa gaya asertif mampu menjadi solusi bagi persoalan yang dihadapi orang tua maupun anak. Tim abdimas berharap dapat memberikan kontribusi yang nyata bagi warga PKK RT 22 RW 9, Juwiring Klaten. Pembentukan komunitas sayang anak juga menjadi solusi bagi keberlanjutan dan pemantauan terhadap keberhasilan kegiatan ini. Pendampingan dilakukan dalam bentuk diskusi baik secara face to face maupun melalui WhatsApp Group dalam rangka menciptakan keharmonisan melalui gaya komunikasi asertif orang tua terhadap anak.
\end{abstract}

Kata Kunci: orang tua-anak; konflik; keluarga harmonis; gaya asertif; pandemi covid 19

\begin{abstract}
Seeing the pandemic conditions that can never be predicted when it will end, parents must have a strategy for children who are confined to their own homes while listening to alarming news. Parents have many additional tasks during SFH, including paying attention to signs of illness in children if they are by following Covid-19 symptoms, signs of stress in children that result in unhealthy eating or sleeping habits, and difficulty with concentration, teaching and get used to complying with health protocols. This can lead to conflict between parents and children, as happened to the families of PKK women in Juwiring sub-district, Klaten. Based on the results of observations made by the community service team, it turned out that there were five pairs of parents and children who were involved in conflicts due to stress during the SFH period, therefore the team offered a solution to overcome these problems. The solution is to hold interviews \& focus group discussions (FGD) and counsel "parent-child assertive style in realizing family harmonization". The FGD here aims to identify in more detail related to parent-child conflicts. Counseling is carried out to increase knowledge in living household life in parent-child pairs. Based on the results of the service, it can be concluded that the assertive style can be a solution to problems faced by parents and children. The community service team hopes to make a real contribution to the residents of PKK RT $22 \mathrm{RW} 9$, Juwiring Klaten. The formation of a loving child community is also a solution for the sustainability and monitoring of the success of this activity. Assistance is carried out in the form of discussions, both face to face and through WhatsApp Groups to create harmony through the assertive communication style of parents to children.
\end{abstract}

Keywords: parent-child; conflict; harmonious family; assertive style; covid 19 pandemic

\section{PENDAHULUAN}

Tidak bisa dipungkiri bahwa efek pandemi covid membuat stres banyak orang. Corona Virus Disease (Covid-19) telah menyerang di 209 negara dan meluluhlantakkan sendi-sendi kehidupan manusia yang 
bermartabat, mulai kesehatan, pendidikan, sosio-komunikasi dan sosio-ekonomi, bahkan menyentuh dimensi implementasi keagamaan. Dampak ini bersifat global, sehingga tak satupun negara di dunia yang mampu menghindar dari mewabahnya virus ini. Dampak ini justeru menghantam mental manusia baik anak maupun dewasa. Bentuk terganggunya mental adalah rasa ketakutan dan kecemasan yang luar bisa terhadap penyakit baru ini. Lebih lagi pada mereka yang telah memiliki penyakit bawaan. Tidak khayal lagi, pandemi Covid-19 memaksa anak-anak terkungkung di rumah bersamaaan dengan kebijakan pemerintah untuk menerapkan belajar, bekerja dan beribadah dari rumah atau dalam bahasa populernya adalah WFH (Working From Home), dan SFH (Study From Home). Segala kegiatan, termasuk belajar harus dilakukan via gawai. Lambat laun, kebiasaan ini menjadikan konsentrasi dan suasana hati anak menjadi labil. Di satu sisi gawai adalah media belajar anak selama masa pndemi, di sisi lain gawai juga menjadi media bermain game di saat waktu luang.

Dinamika pendidikan saat ini akan membawa kita semua pada pergerakan untuk mampu beradaptasi dengan perubahan lingkungan dan perubahan jaman. Perubahan lingkungan saat ini menuntut kita untuk beralih kepada kemandirian belajar via media daring. Dengan dinamika pendidikan ini, maka peserta didik harus menyesuaikan perubahan teknologi. Proses adaptif-kreatif-inovatif menjadi rangkaian kata yang harus dihidupi untuk mencapai pembaharuan yang selalu dinamis memenangkan pergulatan kehidupan saat ini. Kemandirian belajar individu akan menjadi kunci untuk menjalankan proses adaptif-kreatif-inovatif. Dinamika akan terus bertumbuh tergantung kepada potensi diri, keterbukaan akan adanya perubahan dan kemauan untuk bersikap positif serta kemampuan menangkap peluang pengembangan. Perpaduan kecerdasan yang diperoleh dari pendidikan dan kemandirian belajar membuat kita menjadi kreatif, mampu berimajinasi dan memiliki ketajaman intuisi yang tinggi yang pada akhirnya menjadikan kita dapat memiliki kunci keberhasilan untuk berpartisipasi dalam proses pembaharuan semesta [2]

Melihat kondisi pandemi yang tidak pernah bisa diprediksi kapan berakhirnya, orang tua harus memiliki strategi terhadap anak-anak yang terkungkung di rumahnya sendiri sambil mendengarkan pemberitaan yang memprihatinkan. Kecenderungan anak-anak akan bereaksi seperti apa yang mereka lihat dari orang dewasa di sekitar mereka. Ketika orangtua menghadapi pemberitaan wabah Covid-19 dengan tenang dan kata-kata positif, mereka akan dapat memberikan dukungan terbaik untuk anak-anak mereka. Anak-anak juga akan bersikap lebih tenang menghadapi wabah ini.

Orang tua memiliki banyak tugas tambahan selama SFH, antara lain: memperhatikan tanda-tanda penyakit pada anak jika sesuai dengan gejala Covid-19, tanda-tanda stres pada anak yang berimbas pada kebiasaan makan atau tidur yang tidak sehat, dan kesulitan dengan konsentrasi, mengajarkan dan membiasakan tindakan patuh pada protokol kesehatan, membantu anak tetap aktif untuk bermain di luar ruangan, sehingga tetap terhubung secara sosial, membuat jadwal dan rutinitas yang fleksibel untuk belajar di rumah, mengatur waktu tidur yang konsisten dan bangun pada waktu yang sama, dan mempertimbangkan kebutuhan dan penyesuaian yang diperlukan anak [11]

Adapun menurut Kurniati [5], orang tua juga memiliki lima buah peran dalam menjaga anaknya. Peran mereka 5P yaitu sebagai pembimbing, pendidik, penjaga, pengembang sekaligus pengawas Sebagai pembimbing mereka harus menjelaskan kepada anak untuk mau menerapkan hidup bersih dan sehat, sesuai dengan protokol kesehatan yang telah ditetapkan pemerintah. Sebagai pendidik, orang tua harus mendampingi anak dalam mengerjakan tugas sekolah dan melakukan kegiatan bersama selama di rumah. Terciptanya lingkungan yang nyaman untuk anak dalam belajar, diperoleh dari komunikasi yang terjalin dengan intens. Sebagai pendidik, orang tua merupakan role model bagi anak, yang membimbing dan memotivasi anak, memberikan edukasi, serta memelihara nilai keagamaan. Sebagai pengembang, orang tua bisa melakukan variasi dan inovasi kegiatan di rumah agar tidak membosankan. Keempat peran kemudian dikontrol dengan peran kelima yaitu pengawas agar sesuai dengan harapan.

Sebagai pendidik, orang tua tidak ubahnya menjadi guru bagi anaknya di rumah. Keduanya terlibat dalam proses komunikasi dalam kegiatan belajar mengajar. Agar tujuan belajar dari anak tercapai maka dalam interaksi tersebut harus didukung dengan komunikasi yang efektif. Orang tua dapat menggunakan komunikasi dalam bentuk langsung maupun tidak langsung misalnya penyampaian informasi secara lisan, secara tertulis, komunikasi melalui media konvensional, media sosial, maupun melalui komunikasi dalam aktivitas kelompok. Dengan adanya penerapan gaya komunikasi orang tua yang menyenangkan, secara tidak langsung akan dapat juga menumbuhkan semangat atau motivasi belajar anak terhadap tugas-tugas dari guru. Motivasi belajar yang timbul dalam diri anak disebabkan karena adanya cita-cita atau dorongan untuk memperoleh hasil yang diharapkan. Penelitian motivasi belajar dari Vianesa Sucia [7] menunjukkan bahwa gaya komunikasi asertif paling tinggi pengaruhnya terhadap motivasi belajar siswa. Siswa merasa lebih termotivasi, lebih nyaman dan senang apabila seorang guru menggunakan gaya komunikasi asertif.

Dalam melakukan perannya selama SFH, Subarto [8] mengusulkan topik-topik diskusi antara orang tua dengan anak antara lain: mendiskusikan tentang aturan-aturan di dalam rumah, memberikan arah kepada anak bagaimana perilaku yang seyogianya dijadikan contoh, agar anak mendapatkan pedoman untuk mencapai prestasi, memberikan cara yang mudah bagi anak untuk memecahkan masalah yang berkaitan 
dengan kemampuan memelihara hubungan interpersonal dengan guru dan teman kelasnya selama di rumah, menunjukkan cara mengatasi perilaku emosional anak, dan tips menjadi sahabat dan teman dalam berbagi tugas yang berkaitan dengan self-regulating learning (misalnya sebagai teman diskusi dalam menyelesaikan tugas, menjadi teman untuk bertanya).

Di sisi lain tanggung jawab orang tua tidak hanya terbatas pada posisi ibu atau bapak saja. Sebagian orang percaya bahwa ibu lebih pandai dalam berkomunikasi dengan anak, karena sejak dalam kandungan, anak sudah memiliki kontak batin dengan ibunya. Namun bukan berarti peran bapak bisa dianggap tidak efektif dalam berkomunikasi dengan anak.. Mengenai perbandingan gaya komunikasi antara dua budaya yang berbeda yakni budaya maskulin (pria) dan budaya feminin (wanita), tidak menunjukkan bahwa cara berkomunikasi pria lebih baik daripada cara berkomunikasi wanita atau sebaliknya. Namun perbedaan gaya komunikasi tersebut dapat diamati berdasarkan pengkategorian-pengkategorian tertentu, seperti perbedaan saat berbicara, pemilihan topik pembicaraan, cara interupsi, penggunaan kata/kalimat tanya, menggunakan cerita dan guyonan, dan kategori-kategori lainnya [4]

Pengawasan orang tua juga semakin menurun sehingga intensitas komunikasi selama masa pandemi lebih ekstra daripada pengawasan usia anak. Apalagi jika hal ini dikaitkan dengan penggunaan gadget pada masa pandemi. Data yang diungkapkan oleh Asosiasi Penyelenggara Jasa Internet Indonesia ( $\underline{\text { APJII) }}$ menyatakan bahwa pengguna internet tertinggi ada pada segmen umur usia 15-19 tahun mempunyai penetrasi paling tinggi yaitu mencapai 91\% [12]. Bahkan pembangkangan remaja terhadap orang tuanya dibuktikan dalam sebuah penelitian yang menemukan hasil bahwa remaja dengan kepuasan otonomi yang rendah lebih banyak frustrasi dan membangkang, sedangkan anak dengan kepuasan otonomi yang tinggi akan sedikit membangkang dan lebih banyak negosiasi [6]

Berada di dalam rumah selama berbulan-bulan sangat memungkinkan terjadinya kebosanan pada rutinitas. Tingkat stres pun meningkat. Ketidaksiapan tersebut pada akhirnya melahirkan konflik dengan orang sekitar, terutama anak. Anak menjadi pelampiasan kemarahan orang tua. Gaya komunikasi orang tua menjadi non asertif bahkan agresif. Berdasarkan latar belakang masalah tersebut maka konsep gaya komunikasi orang tua terhadap anaknya baik dengan usia anak maupun usia remaja pada masa pandemi covid 19 menarik untuk dibahas.

Berdasarkan hasil observasi di desa Karasan, Kenaiban, Klaten, ditemukan beberapa kasus keluhan atas perilaku anak dalam proses pembelajaran sehingga menimbulkan konflik antara orang tua-anak (hasil wawancara dengan Endah Sri Suranti, Ketua PKK, Januari 2021). Beberapa konflik yang terjadi bisa dilihat dalam tabel 1 .

Tabel 1. Pasangan Orangtua dan Anak yang Berkonflik

(Sumber : Hasil Wawancara dengan Ketua PKK Januari 2021)

\begin{tabular}{llcl}
\hline No. & $\begin{array}{l}\text { Pasangan konflik } \\
\text { (insial orang tua-anak) }\end{array}$ & Sumber konflik & Bentuk konflik \\
\hline 1. & DT - DW & Pendampingan & menghindar \\
2. & HJ - MN & dalam & Verbal \\
3. & PW-MN & daring & Venghindar \\
4. & TH-ES & & menghindar \\
5. & RT-TH & & \\
\hline
\end{tabular}

Adapun analisis SWOT dari mitra mencakup analisis kekuatan dan kelemahan, peluang serta ancaman. Kekuatan mitra terletak pada keaktifan anggota kelompok dalam berpartisipasi dalam kegiatan rutin maupun non rutin. Kohesivitas diantara mereka cukup baik sehingga kelompok PKK ini cukup solid meski dalam situasi pandemi sekalipun. Mereka memiliki WA group untuk menyebarkan informasi penting, sedangkan pertemuan tatap muka masih sebatas dihadiri pengurus organisasi. Namun kelemahan dari kelompok mitra antara lain komunikasi interpersonal diantara mereka memiliki keterbukaan yang relatif kurang. Hal ini ditandai dengan masih terdapat rumor-rumor diantara mereka yang tidak jelas sumber dan kebenarannya. Terkadang hal ini dapat memicu munculnya gap-gap diantara anggota. Adapun adanya pendanaan rutin tahunan PKK dari lembaga pemerintah untuk memberdayakan organisasi menuju kemanfaatan kehidupan organisasi maupun rumah tangga anggota menjadi peluang organisasi untuk bisa berkembang. Namun adanya bentuk kreativitas dari kelompok PKK desa tetangga yang mengakibatkan kecemburuan dan persaingan yang tidak sehat diantara organisasi PKK dalam satu desa merupakan ancaman yang nyata dan merugikan organisasi. Dengan demikian terlihat bahwa persoalan komunikasi masih menjadi prioritas dari kelompok mitra. Hal ini terlihat dari rumor yang masih berkembang diantara mereka (Wawancara dengan ketua PKK, Januari 2021). 


\section{METODE}

Berdasarkan hasil observasi yang dilakukan oleh Tim abdimas sebagaimana yang disebut di atas, Tim telah berhasil diidentifikasi beberapa permasalahan mitra. Adapun solusi yang Tim tawarkan untuk mengatasi permasalahan tersebut adalah sebagai berikut:

1) Wawancara dan Focus Group Discussion (FGD)

FGD disini bertujuan untuk mengidentifikasi lebih mendetail terkait konflik orang tua anak. FGD ini melibatkan kader, dan pasangan orang tua anak. Selain itu, juga akan dilakukan pengukuran terhadap tingkat penyelesaian konflik yang dilakukan oleh orang tua-anak dalam relasi keluarga.

2) Penyuluhan "gaya asertif orang tua-anak dalam mewujudkan harmonisasi keluarga"

Penyuluhan ini dilakukan untuk meningkatkan pengetahuan dalam menjalani kehidupan rumah tangga pada pasangan orang tua-anak. Target yang diharapkan dari penyuluhan ini bertujuan untuk meningkatkan kesadaran orang tua dalam menanamkan pendidikan yang tepat kepada anak. Kesadaran ini diterapkan dalam kehidupan sehari-hari dengan menerapkan program keluarga harmonis. Penyuluhan dilakukan sebanyak 2 (dua) kali, dengan menghadirkan narasumber yang ahli dalam bidang komunikasi. Tema penyuluhan meliputi:

a. Tanggung jawab orang tua menurut perspektif Islam

b. Managemen konflik interpersonal dalam pasangan orang tua anak melalui penerapan gaya asertif.

c. Gaya asertif orang tua ke anak sebagai solusi

\section{HASIL DAN PEMBAHASAN}

Dengan penyuluhan diharapkan dapat meningkatkan pengetahuan anggota PKK untuk menjadi orang tua yang asertif dalam membimbing anak-anaknya belajar di masa pandemi sebagaimana dikatakan Sudarta [9] bahwa peningkatan pengetahuan merupakan langkah yang sangat penting sebagai tahap awal dalam suatu proses adopsi inovasi dan akan memperbaiki keterampilan peserta.

Penayangan film tentang akibat pertengkaran orang tua-anak dilanjutkan diskusi. Penayangan Film di sini bermanfaat sebagai media literasi dalam memahami relasi hubungan orang tua-anak serta managemen konflik interpersonal. Setelah itu dilakukan diskusi dan simulasi tentang isi film. Dengan demikian orang tua yang bersangkutan dapat mengungkapkan kesulitan maupun keinginan terhadap kondisi anak. Gaya asertif semakin penting untuk mendapatkan perhatian dalam rangka mewujudkan iklim harmonis dalam keluarga.

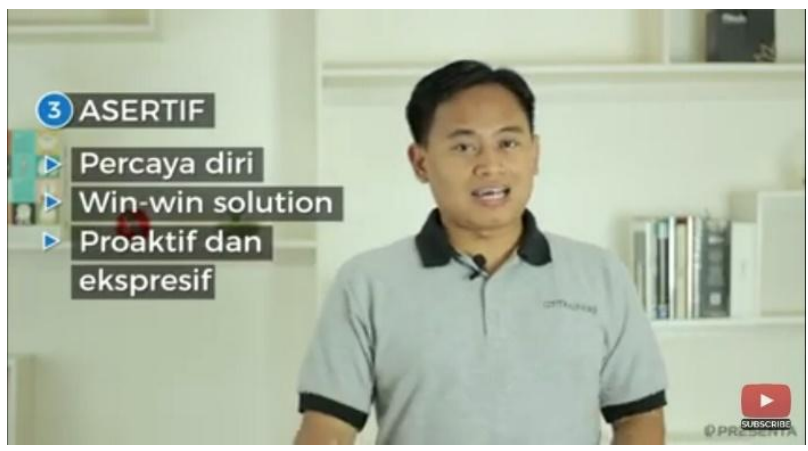

Gambar 1. Film tentang Ciri Komunikator yang Asertif

Menurut Pratista [1] film pada dasarnya terdiri atas dua unsur pembentuk yakni, unsur naratif dan unsur semantik. Dua unsur tersebut saling berinteraksi dan berkesinambungan satu sama lain. Unsur naratif adalah bahan (materi) yang akan diolah atau berhubungan dengan aspek cerita atau tema film, seperti tokoh, masalah yang diangkat dalam film tersebut, konflik, lokasi maupun waktunya. Sementara itu unsur sinemantik adalah cara (gaya) untuk mengolah dan bisa dikatakan juga merupakan aspek-aspek teknis dalam produksi sebuah film. Dengan demikian, melalui kelebihan film, peserta diajak untuk memahami realitas secara audio visual terkait dengan pentingnya menjadi sosok asertif dalam keluarga mereka.

Pembuatan poster dan modul keluarga harmonis. Pembuatan poster dan modul di sini bertujuan untuk menjadi "retention" dalam setiap pasangan orang tua-anak ketika menjalin komunikasi. Isi poster meliputi penanaman kesadaran tanggung jawab orang tua terhadap anak, pentingnya berkomunikasi secara intens dan terbuka dengan anak, serta pentingnya menerapkan gaya komunikasi asertif sehingga konflik orang tua-anak akan bisa diselesaikan secara dengan baik. 


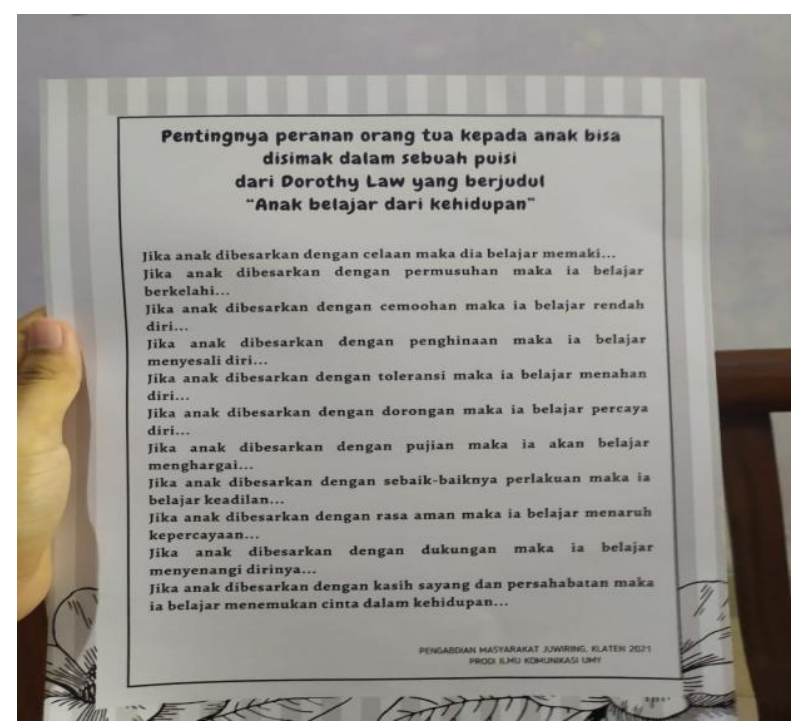

Gambar 2. Poster Peranan Orang tua bagi Anak

Sebuah poster memiliki keunggulan sebagai media penyuluhan, yaitu: 1) citra visualnya mampu menyampaikan pesan secara cepat dan langsung; 2) mampu menjangkau sasaran lebih banyak; 3) dapat ditempel ditempat yang strategis dimana saja; dan 4) mudah dan cepat dimengerti, termasuk oleh mereka yang buta huruf. Media ini akan menjadi media yang gampang diingat oleh peserta, sehingga pesan lebih cepat diingat dan dipahami.

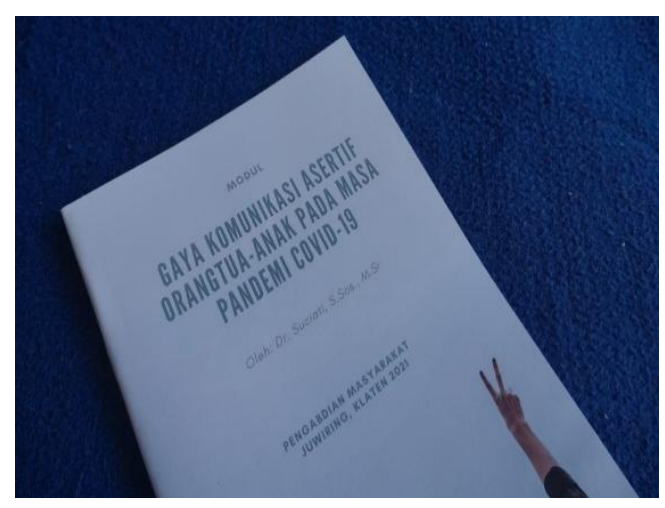

Gambar 3. Modul Gaya Komunikasi Asertif

Pada dasarnya sebuah modul adalah materi pembelajaran yang bisa mengantarkan peserta kepada tataran operasional. Sebagaimana hal ini dikatakan oleh Erlely [3] bahwa modul pada dasarnya berisikan pemecahan masalah yang sedang dihadapi serta petunjuk atau rekomendasi teknis yang perlu dilaksanakan pada kegiatan secepatnya.

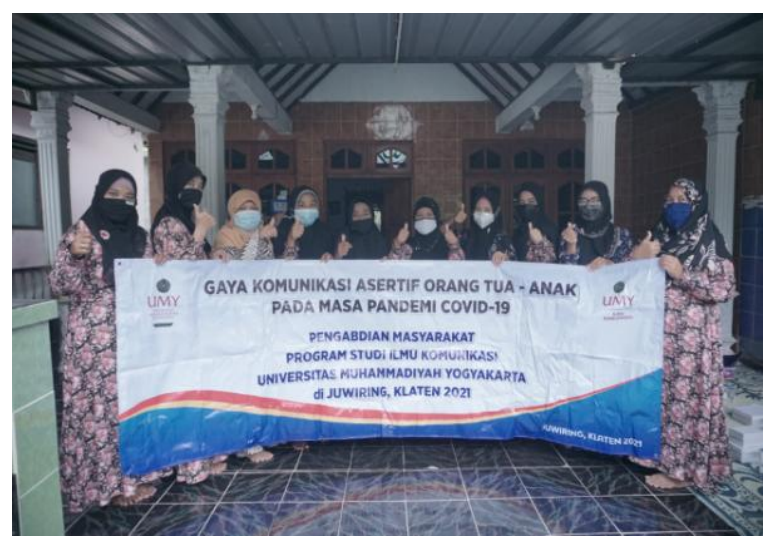

Gambar 4. Komunitas Sayang Anak 
Pembentukan Komunitas Sayang Anak. Pembentukan komunitas ini bertujuan untuk menunjang keberlanjutan program komunikasi intens dalam keluarga harmonis, sehingga ada anggota penerus yang akan menjadi pengerak terkait pengelolaan konflik orang tua-anak. Komunitas ini nantinya akan beranggotakan pasangan orang tua-anak. Melalui komunitas ini bisa dirumuskan kegiatan-kegiatan untuk mendukung terwujudnya keluarga harmonis.

Program Kemitraan Masyarakat ini memiliki rencana target luaran yang ingin dicapai, yaitu publikasi pada jurnal ISSN, repositori UMY, media massa, dan video kegiatan. Adapun luaran yang sudah tercapai antara lain:

a. Publikasi di Harian Jogja pada tanggal 17 April 2021 dalam link: https://pengabdianumy.harianjogja.com/read/2021/04/17/559/1069254/pkm-umy-perkenalkan-gayakomunikasi-asertif-untuk-selesaikan-konflk-orang-tua-anak-di-klaten

b. Video pelaksanaan yang dipublikasi di youtube $: \underline{\text { https://youtu.be/zsc52CZQCnA }}$

Perencanaan program pengabdian masyarakat yang dilakukan oleh tim telah sesuai dengan kebutuhan para mitra pengabdian masyarakat, mitra menjawab delapan pertanyaan tingkat kepuasan dengan jawaban sangat puas. Adapun pertanyaan kuesioner mencakup antara lain: perencanaan program pengabdian masyarakat, pelaksanaan program pengabdian masyarakat telah dilakukan sesuai kaidah metode pelaksanaan pengabdian masyarakat, pelaksanaan program pengabdian masyarakat telah dilaksanakan dengan memperhatikan K3 (Keselamatan dan Kesehatan Tenaga Kerja), hasil pengabdian masyarakat sesuai dengan solusi yang diharapkan oleh mitra pengabdian masyarakat, hasil pengabdian masyarakat dapat dimanfaatkan secara maksimal, pendanaan pengabdian masyarakat telah dirasakan cukup memadai bila dibandingkan dengan hasil yang diharapkan. Adapun pada bagian saran/masukan dari mitra adalah harapan kerjasama bisa dilanjutkan (Hasil analisis kuesioner kepuasan mitra pada April 2021).

\section{KESIMPULAN}

Pandemi covid 19 yang belum reda, mengharuskan anak maupun orang tua berada di dalam rumah selama berbulan-bulan. Hal ini bisa mengakibatkan kebosanan pada rutinitas. Lebih-lebih bagi orang tua yang biasa bekerja di luar rumah, rasa bosan akan menaikkan emosi negatif, ditambah harus menjadi guru bagi anaknya. Padahal ketrampilan pedagogik tidak dimiliki oleh semua orang tua. Tingkat stres pun meningkat. Ketidaksiapan tersebut pada akhirnya melahirkan konflik dengan orang sekitar, terutama anak. Anak menjadi pelampiasan kemarahan orang tua. Gaya komunikasi orang tua menjadi non asertif bahkan agresif. Di sisi lain, terbukti dalam banyak penelitian bahwa gaya asertif mampu menjadi solusi bagi persoalan yang dihadapi orang tua maupun anak. Tim abdimas berharap dapat memberikan kontribusi yang nyata bagi warga PKK RT 22 RW 9, Juwiring Klaten. Pembentukan komunitas sayang anak juga menjadi solusi bagi keberlanjutan dan pemantauan terhadap keberhasilan kegiatan ini. Pendampingan dilakukan dalam bentuk diskusi baik secara face to face maupun melalui WA dalam rangka menciptakan keharmonisan melalui gaya komunikasi asertif orang tua terhadap anak.

\section{DAFTAR PUSTAKA}

[1] Himawan, Pratista., "Memahami Film", Homerian Pustaka, 2018.

[2] Sanjaya, Ridwan., "21 Refleksi Pembelajaran Daring di Masa Darurat", Universitas Katolik Soegijapranata, 2018

[3] Erlely, Wista., "Materi Penyuluhan", 2019

[4] Juliano P, Sangra, "Komunikasi dan Gender: Perbandingan Gaya Komunikasi dalam Budaya Maskulin dan Feminin", Jurnal Ilmu Politik dan Komunikasi, Volume V No.1, 2015

[5] Kurniati, dkk., "Analisis Peran Orang Tua dalam Mendampingi Anak di Masa Pandemi Covid 19", jurnal Obsesi, 2020

[6] Petegem, et all., "Adolescents' responses to parental regulation: The role of communication style and selfdetermination", in Journal of Applied Developmental Psychology Volume 65, November-December, 2019

[7] Sucia, Vianesa., "Pengaruh Gaya Komunikasi Guru Terhadap Motivasi Belajar Siswa", Jurnal Komuniti Vol. VIII, No.2, 2016

[8] Subarto, "Momentum Keluarga Mengembangkan Kemampuan Belajar Peserta Didik Di Tengah Wabah Pandemi Covid-19", Buletin Hukum dan Keadilan, Vol. 4, No. 1, 2020

[9] Sudarta, W.,"Pengetahuan dan Sikap Petani Terhadap Pengendalian Hama Tanaman Terpadu", 2005.

[10] Wellyana, "Poster", 2019.

[11] kompas.com 9 April 2020

[12] inet.betik.com16 Mei 2019 